\title{
DIABEŁ W FILOZOFII NOWOŻYTNEJ
}

Ernest Gellner

Filozofię nowożytną, począwszy od Kartezjusza aż po obecne pokolenie filozofów, można zdefiniować jako wiarę w diabła. Tym, co spaja pokartezjańską filozofię, jest demon. Stworzył go Kartezjusz, a wszyscy pozostali w niego wierza. W jaki sposób i dlaczego go stworzył? Jak powszechnie wiadomo, badając chaos przeszłych błędów i zauważając, że zawsze znajdował się ktoś gotów uwierzyć w największy nawet absurd, Kartezjusz miał nadzieję, że rozum może własnymi silami wyzwolić się od każdego możliwego błędu. Jednak by tego dokonać, trzeba zacząć od zera. Jeśli zaś chcemy rozpocząć od zera, podstawową trudnością jest znalezienie owego punktu zerowego - tego solidnego punktu, z którego będzie można rozpocząc zupełnie nowe, ale bezpieczne rozumowanie. W tym właśnie miejscu pojawia się hipoteza diabła: wyobraź sobie złośliwego i wszechpotężnego diabła, którego celem jest zwodzenie cię, przede wszystkim w twoich próbach dowiedzenia się czegoś o świecie.

A teraz spróbuj z pełna powaga przyjąć to założenie i zobacz, które z twoich przekonań wytrzymają tę próbę: bardzo nieliczne, jeśli w ogóle jakiekolwiek. Może się okazać, że niektóre z nich przetrwają. Być może istnieja pewne przekonania, które - nawet przy założeniu o złośliwym demonie, ingerującym w nasze sprawy - musza pozostać niepodważalnie prawdziwe. Jeśli takie rzeczywiście istnieją, to one właśnie stanowia ów punkt zerowy. Muszą być podstawą, solidną i naprawdę wiarygodną bazą, fundamentem dla nowego gmachu. Taką funkcję pełniła u Kartezjusza hipoteza diabła, użyta jako papierek lakmusowy, środek oddzielający to, co jest absolutnie pewne, od tego, co się takim jedynie wydaje. Zauważmy, że istnienie diabła nie jest tu wcale konieczne, potrzebna jest tylko hipoteza, a nie jego realne istnienie. Trzymając się faktów historycznych, trzeba podkreślić, że sam Kartezjusz nie wierzył w jego istnienie. Przeciwnie, uważał, że dojście do prawdy poprzez rygorystyczne myślenie zostało zagwarantowane przez łaskawego Boga.

Owa solidna podstawa, którą Kartezjuszowi udało się odnaleźć dzięki swojej metodzie, jest dobrze znana: myślę, więc jestem. Mogę wattpić 
we wszystko, ale watpienie samo w sobie jest przypadkiem myślenia, a więc istnieję.

Można wątpić we wszystko, wszystko podejrzewać o bycie diabelskim złudzeniem, oprócz własnego istnienia. Stwierdzenie to może być interpretowane na (co najmniej) trzy sposoby. Po pierwsze, jako to, co współcześni filozofowie nazwaliby „paradoksem pragmatycznym”, polegającym na tym, że samo pojawienie się watpliwości jest przypadkiem myślenia, a więc samo wątpienie dowodzi istnienia myśli. Może być też rozumiane jako argument z pewności i niepodważalności bezpośrednich danych świadomości. Lub jeszcze inaczej, może być interpretowane jako argument głoszący, że działanie wymaga działającego, przejaw wymaga substancji, której jest przejawem. Którąkolwiek z tych interpretacji przyjmiemy, przedłożone argumenty maja interesujące następstwa. Co sam Kartezjusz zrobił ze swoją opoka, gdy ją odnalazł - w tym momencie nas nie interesuje.

Dla większości filozofów po Kartezjuszu diabeł bynajmniej nie był fikcja. Nie było tak, że zakładając jego istnienie, trwali zarazem w przekonaniu, że go nie ma. Wręcz przeciwnie, mocno wierzyli, że szatan istnieje. Kolejni filozofowie moga być sklasyfikowani ze względu na to, z czym go utożsamiali.

Pierwsza teoria głosiła, że diabłem był nasz własny umysł. To właśnie on organizował tworzenie systematycznych fałszywych przedstawień, których Kartezjusz się obawiał, choć tak naprawdę nie sądził, że tak się dzieje. To nasz własny umysł sprawia, że wierzymy w istnienie rzeczy, których tak naprawdę nie ma, albo przesłania istnienie tych, które są. Istnieje wiele wariacji na ten temat. Przykładowo, można utrzymywać, że nasz umysł zwodzi nas przez zbytnie zawierzenie zmysłom. Ale zakładano też, że zwodzi nas przez nadmierne oddawanie się abstrakcyjnemu myśleniu.

Druga ważna teoria głosi, że diabeł jest historią. Wyrosła ona zupełnie naturalnie z wcześniejszego utożsamienia demona z umysłem. Myśliciele tacy jak John Locke czy David Hume sądzili, że ich badania dotyczą ludzkiego rozumienia lub natury ludzkiej jako takiej, że poprzez wnikliwa analizę umysłu będą w stanie powiedzieć nam wystarczająco dużo o zwyczajach owego demona, by każdy i wszędzie mógł być zawczasu ostrzeżony. Nie było bynajmniej tak, żeby na przykład Hume nie był świadom tego, co moglibyśmy nazwać relatywizmem kulturowym; jednak koniec końców, umysł był wszędzie ten sam - i szatan był ten sam.

Przejście od utożsamiania demona z umysłem do utożsamiania go z historią nastapiło po Kancie i zapowiedź tego była być może zawarta implicite w niektórych jego poglądach. O ile dla Kanta prawda wciąż była jedna, to (już) błąd nie był przypadkowy. Błąd, tak samo jak prawda, odzwierciedlał strukturę umysłu (być może nawet bardziej) - podstawowe 
błędy, jakie istnieją, są zewnętrznymi przejawami czegoś istotowego w nas i z tej racji będą pojawiać się w pewnych układach. Błędy, które dostrzegamy, patrząc wstecz na historię myśli, nie przypominaja losowego rozrzutu strzałów wokół środka tarczy, nużącego zapisu prób i błędów z przewaga tych drugich. Wręcz przeciwnie, sa raczej podobne do cyfr, pojawiających się regularnie na szwajcarskim zegarku.

Lecz skoro błąd może być głęboko odkrywczy, a nawet wykazywać tendencję do występowania w pewnych wzorach, dlaczego to samo nie ma dotyczyć prawdy? W istocie już tylko krok dzieli nas od takiej konkluzji. Po Kancie znacznie rzadziej przyjmowano za oczywiste, że umysł przybiera niemal identyczna postać u wszystkich ludzi. Źródła systematycznego błędu nie szukano już w mechanice umysłu, lecz w historii, w czasowym, geograficznym i społecznym podłożu wiedzy. Diabeł, który zakłóca nasze postrzeganie rzeczywistości, przybrał nowy kształt. Historycystyczne demonologie, takie jak marksistowska czy spenglerowska, ukazuja, jak sama demonologia stanowi wyjątek od demonicznego wypaczenia, a nawet jak sam demon jest gwarantem jej prawdy. Historyczny diabeł jest dziś daleki od śmierci. Mimo iż doktryna głosząca, że człowiek jest niewolnikiem historii, pozostaje wciąż żywa i inspirująca, aktualnie to nie ona dominuje. Demon panujący dziś, przynajmniej w tym kraju, to język. Sposób, w jaki językowy diabeł rozwinął się z historycznego, to subtelna sprawa, jednak można wykazać logiczny związek.

Bieg wydarzeń wyglądał następująco: po Darwinie demon historii łączony był ze spokrewnionym z nim demonem natury - naturalizm towarzyszył historyzmowi lub wręcz zajął jego miejsce. Pod wpływem postępu w biologii rozkwitły teorie głoszące, że demon jest natura. Najbardziej znaną spośród nich jest pragmatyzm. Myślenie, szacowanie, wiedza zaczęły być postrzegane jako naturalny proces, rządzący się prawami podobnymi do praw przyrody w ogóle. Kieł tygrysa i szyja żyrafy były zasadniczo zjawiskiem tego samego rodzaju, co wnioskowanie geometryczne oraz dziesięć przykazań. To sprowadzało się do wydania naturze związanej i zakneblowanej myśli. Niektórzy filozofowie opierali się różnym „izmom” - psychologizmowi, historyzmowi, naturalizmowi interpretującym wiedzę i prawdę jako manifestację tej, tamtej czy jeszcze innej siły, kontrolującej myśl i nas wszystkich. Ci filozofowie poszukiwali schronienia przed wspomnianymi demonami w logice i przyczynili się tym samym do jej odrodzenia, które miało miejsce na przełomie XIX. i XX. stulecia. Nowe zainteresowanie logiką było motywowane po części determinacja, aby zobaczyć myśl raczej jako rzeczywiście prawdziwą lub rzeczywiście fałszywą niż jako pokaz diabelskich sztuczek. 
Problemy powstały jednak nawet w logice - na skutek dociekań u jej podstaw uznano, że nie jest ona bynajmniej tak odporna na błędy. Logika jest zakorzeniona w języku - i w ten sposób narodził się nowoczesny diabeł językowy.

Jest też dość słynny demon psychoanalityczny lub nieświadomy, wywodzący się - dzięki Schopenhauerowi - od swego przodka, diabła umysłu z domieszką biologicznego członka diabelskiej rodziny.

Sugerowałem, że typy filozofii nowożytnej od czasów Kartezjusza moga być postrzegane jako rywalizujące ze sobą utożsamienia demona z umysłem, historia, biologiczną natura, nieświadomym umysłem, językiem. Można je nazwać diabologiami porównawczymi. Ale istnieje też inny interesujacy sposób uszeregowania nowożytnych filozofów, który można by nazwać demonologią różnicująca.

$\mathrm{Na}$ jednym końcu skali możemy umieścić tych, którzy decydują się walczyć, którzy chcą przechytrzyć diabła. Doszedłszy do wniosku, że diabeł istnieje, że coś systematycznie zakłóca nasze dążenie do wiedzy, filozofowie ci uznaja, że ich zadaniem jest znalezienie sposobów i środków zastawienia nań pułapek. To oni dają nam reguły myślenia, dostarczają gotowych metodologii, które - jeśli ich uważnie przestrzegać - działaja jako talizmany przeciwko błędom. Filozofowie ci dają nam formalne recepty na to, jakie muszą być prawda lub znaczenie. Postrzegają się jako swego rodzaju tajne służby wiedzy, tropiące wśród nas agentów-prowokatorów i wysyłające szpiegów, aby przekazali nam plany wroga.

$\mathrm{Na}$ drugim końcu tej skali sa filozofowie, którzy niejako wyciagaja logiczny wniosek $z$ faktu, iż demon jest wszechmocny. Jeśli zwodziciel rzeczywiście jest wszechmocny, jaki ma sens starać się go przechytrzyć? Jeśli jest wszechmocny i systematyczny, czy jego oszustwa nie moga być „nazwana-na-nowo” prawdą? Czy nie możemy poddać się i mieć to z głowy? Wśród filozofów było wielu takich kolaborantów. Trudno nazwać ich zdrajcami, choć zarzut zdrady klerków jest po części skierowany pod ich adresem. W tym przypadku nie była to jednak zdrada, jako że filozofowie ci utrzymywali, że przy z założenia wszechpotężnym wrogu ich strategia musi działać. Tego rodzaju filozofowie nie wymyślaja w istocie strategii, ale próbuja złagodzić drogę przez mękę, wyjaśniając bezcelowość oporu, a nawet samego życzenia sobie, by ktoś mógł ten opór stawiać. Bezcelowy lament, w najszerszym znaczeniu tego wyrażenia, stał się w najnowszej filozofii niemal terminem technicznym (filozofowie tego rodzaju tłumaczą nam, przykładowo, że bezcelowym jest chcieć wiedzieć, jakie rzeczy są naprawdę, w przeciwieństwie do tego, jakimi się wydaja, gdy je widzimy czy ich dotykamy; że bezcelowym jest chcieć znać prawdę inną niż zapośredniczona przez język, i tak dalej). 
Oczywiście, nie ma potrzeby, by każdy filozof był bez reszty buntownikiem lub bez reszty kolaborantem. Wielu, czy wręcz większość z nich, jest rozproszona gdzieś pomiędzy tymi dwiema skrajnościami. Można uważać się za zdolnego do przechytrzenia demona tylko w niektórych sferach. Dlatego na przykład Kant stał gdzieś pośrodku. Jego główne dzieło, trzy wielkie Krytyki, jest zasadniczo studium różnych zwyczajów i działań demona umysłu. Demon uchodził za niezwyciężonego do tego stopnia, że nie moglibyśmy obejść się bez niego i przełamać wywoływanych przezeń nawyków, choć nie na tyle, by móc ukryć swoje sztuczki przynajmniej od czasu, gdy odkrył je nam Kant. Musimy z nimi żyć, ale przynajmniej wiemy, na czym polegaja. Te groźniejsze, te, które wiodą nas w ślepy zaułek, można było zneutralizować, jeśli nie wyplenić. Ale w jednej sferze Kant deifikował demona: zrównując moralność z racjonalnościa, zrównał prawdę moralną z tym, co narzuca umysł. Ci, którzy kolaborują z diabłem, usprawiedliwiaja to często, przypisując mu dobrą naturę. Istnieje teoria socjologiczna, która czyni oszustwo ważnym dla zachowania spójności społecznej. Człowiek podpisuje się w pewnym sensie pod przekonaniami, których nie uważa za prawdziwe, ponieważ są one w jego pojęciu narzędziami łaskawego, jeśli już nie wszechmocnego, demona. Dlatego też ludzie gotowi są podpisywać się pod mitologiami, które - jak sądzą - pełnią pożądane funkcje polityczne lub społeczne. Jest to zaprawdę przypadek pomagania biednemu diabłu, który już nie zwodzi, lecz występuje jako rzecznik dobrych chęci.

Współczesna filozofia w Wielkiej Brytanii dążyła w ostatnich dekadach do przechytrzenia diabła za pomoca perfekcyjnego języka i logiki; miały one stanowić wodę święconą, która trzymałaby go na dystans. Za każdym razem, gdy zatrąciło siarką metafizyki czy z pozoru nierozwiązywalnego problemu, zaklęcie redukujące problem do starej dobrej gramatyki logicznej przywracało porządek. Od tego czasu, choć diabeł nadal był utożsamiany z językiem, doprowadzono do niemal zupełnego ubóstwienia języka. Tak więc, cokolwiek język uczyni, jest ipso facto w porządku. Najważniejsza szkoła - oksfordzka - ogłosiła entuzjastycznie powrót staromowy. Obecnie są oni tak entuzjastycznymi kolaborantami, że ich największą frajda jest odnajdywanie buntowników, przyłapanych ze starą logiczną bronią w rękach.

Najnowsza wersja językowego demona jest o tyle ciekawa, że zakres, w którym trzeba z nim walczyć, w rzeczywistości bardzo się skurczył. Wszystkie powszechne aktywności - naukowe czy codzienne - są niemal całkiem wolne od niepożądanych machinacji. Tylko dawne teorie filozoficzne - metafizyczne czy pozytywistyczne - ujawniaja sprawki diabła. Cóż za interesująca odmiana! Codzienne bezrefleksyjne doświadczenie i myśl 
w przeszłości uważane były niekiedy za zasłonę, przez którą filozof musi przejść, by odnaleźć prawdziwą rzeczywistość. Według nowej szkoły to owa zasłona jest rzeczywistością; iluzją jest uznawanie jej wyłącznie za zasłonę. Kartezjusz dał początek nowej filozofii poprzez zwattpienie praktycznie we wszystko. Nowa szkoła rozpoczęła kolejna, poprzez systematyczny brak zwątpienia (nazywa się to zdrowym rozsądkiem lub szacunkiem dla potocznego użycia). Albo, odwołując się do innej przypowieści: filozofia jest nadal postrzegana w kategoriach platońskiej jaskini, jednak teraz zadaniem filozofa jest zaprowadzić nas do niej z powrotem.

Przekładu dokonało Koło Socjologii Teoretycznej przy Kolegium MISH UW

/// Ernest Gellner, The Devil in Modern Philosophy, in: Selected Philosophical Writings, Volume 3, Copyright (C) 2003 Routledge. Reproduced by permission of Taylor and Francis Books, UK. 